\title{
Political Issues on the Colors of the Thai National Flag: Competitions for Meanings in Thai Society
}

\author{
Peeranat Pratoomchartpakdee ${ }^{1} \&$ Kettawa Boonprakarn ${ }^{2}$ \\ ${ }^{1}$ Arts Program in Human and Social Development, Faculty of Liberal Arts, Prince of Songkla University, Hat \\ Yai, Songkhla, Thailand \\ ${ }^{2}$ Faculty of Liberal Arts, Prince of Songkla University, Hat Yai District, Songkhla Province, Thailand \\ Correspondence: Peeranat Pratoomchartpakdee, Faculty of Liberal Arts, Prince of Songkla University, Hat Yai \\ District, Songkhla Province, 90110, Thailand. E-mail: nat_n11@hotmail.com
}

Received: November 2, 2014 Accepted: March 3, 2015 Online Published: May 15, 2015

doi:10.5539/ass.v11n15p39 URL: http://dx.doi.org/10.5539/ass.v11n15p39

\begin{abstract}
The purpose of this study was to examine the competitions in Thai society for the meanings of the colors of the Thai national flag. The data were classified into categories, interpreted, then presented with descriptive analysis. The study found that the meanings of the colors of the national flag depended on the context of each situation where the flag was used as follows. 1) The colors of the national flag are used to represent the country as a nation state. This is when the flag is used abroad in sports competitions, and it is used on sports shirts, the waving flag to show it as a symbol of their nation state. 2) The colors of the national flag are used as a political symbol. This is when the flag is printed on various kinds of products such as ribbon hair bows, plastic clapping hands that people use to show their love for the nation, religion, and the King. 3) The colors of the national flag are used as a sacred object. This is when the flag is used prestigiously to cover the coffins or cremated bones of individuals who have been killed on duty or in service to show their bravery and sacrifice for the country. 4) The colors of the national flag are used as a welcoming sign for HM the King. This is when the flag is used to decorate places to welcome a royal visit, and for people to wave to show their respect and love to HM the King. 5) The colors of the national flag are used to indicate government ownership. This is when the flag is used to show government's ownership of places such as government premises to show that they are under the government power, and the government workplace.
\end{abstract}

Keywords: colors of the national flag, symbol, competitions for meanings

\section{Introduction}

\subsection{Introduce the Problem}

The national flag shows the identity of an independent country prosperous with culture. The country's pride in its dignity as an independent nation is shown through the national flag that all countries value as the spiritual center of all people in the country. Therefore, the national flag is a symbol of the country that all people in the nation must respect and uphold over other things.

The Thai national flag symbolizes Thainess, and shows the pride of Thai people. Before the existence of the present flag, the national flag had been developed and changed several times in the past until in 1927, HM King Prajadhipok (King Rama VII) considered that the national flag had been through several changes, and it should permanently remain with the same design. Consequently, King Rama VII sent a memorandum to the privy council to seek the opinions of the majority of the privy councilors whether to use the tricolor flag or Thong Trirong or to return to the use of the Elephant Flag or Thong Chang or to change the design and the use of the tricolor flag. The result was that they were divided in their opinion and could not present a unanimous decision. HM King Rama VII, therefore, made a decision on May 25, 1927 to continue using the tricolor flag as the national flag of Thailand (Gazette, 1986).

Even though all Thai citizens have the right to use the colors of the Thai national flag, the use of the flag must be in accordance with the law. Presently, the national flag is used in many occasions such as international games, where the use of the flag is to be in accordance with the regulations of the international sports society or according to the accepted international principles. For example, the flag is used on athletes' shirts to identify the 
country that the athletes represent, to wave it or to put it over the shoulders of winning athletes. The flag is painted on parts of the body, especially the face, to show who or what country the individuals cheer. Moreover, the national flag is used to honor the body or cremated bones of individuals who have died on duty such as in fighting, battling, or keeping peace and order of the country. The flag is used to cover the body of the deceased in the bathing ceremony or in a religious ceremony for the deceased (Gazette, 1986).

Recently, the colors of the national flag were used to show political preferences, especially during $2013-2014$, after the political situation had been stable for a while, and November 1, 2013 was the start when various groups of people led by Suthep Thaugsuban protested the government. A political rally usually stems from groups of people who have the same goal. So, it is necessary to have a symbol, an essential element that is "the center point" that functions as a "magnet" to attract people to participate and support the rally in order to achieve the goal. The basic elements of a political rally consist of a key person, a situation, and content. However, to involve a mass of people as many as possible, another essential element is needed, that is a "symbol" that helps gather other elements to become one texture, and helps facilitate communication between core leaders and rally's participants and vice versa. The most prominent "symbols" in one of Thai political rallies were "colors" and "objects" that enhanced the rally's atmosphere, and "Yellow" and plastic "clapping hands" were used as symbols of the People's Alliance for Democracy (PAD) in 2008 (Chuanpipatpong, 2014).

The use of the colors of the national flag and the flag as symbols of this political rally can be considered the only place in the world where such symbols induced economic values. The national flag, and whistles in the symbolic colors of the rally functioned as linkages of problems of the country, and as indicators of the government's faults and frauds. The colors of the flag in many different products reflected change from personal identity to adapting it to accessories that people wore in their daily life such as eye glasses, ribbon hair bows, hair bands, clothing, hats, caps, whistle chains, etc. These everyday life accessories reflected people's taste, and everyone could think of using these symbolic colors in anyway they thought suitable.

The significant issue that prompted the researcher to conduct this study was the competitions of the symbolic meanings of the colors of the Thai national flag because in the past, national flags were used as symbols of nation states and contained the meaning of being a nation or ideologies of the state. National flags of all nations are certified by their own states, either by laws relating to the flag or clauses in the constitution relating to the use of the flag. In the past, using the flag was a taboo in many situations, and the flag was to be highly respected, which was different from today where the flag is used to show patriotism and political preferences.

As time passes, the importance of the colors of the flag has changed from abstract indicating patriotism to concrete objects showing patriotism and being a nation in a form of products such as ribbon hair bows, headbands, wristbands, patterns on hand bags, patterns on clothing, and many others. Certainly, the Thai national flag is still highly respected and valuable to Thai people as it has always been. However, there have recently been competitions for meanings of the values that have been used symbolically, or in a way that can be referred to as consumption of signs, in Thai society. These phenomena brought questions for the research to find out. One is how the meanings of the colors of the Thai national flag have been competed for, another is how Thai society has consumed the colors of the Thai national flag in such a way that can be called consumption of signs, and the other is how the colors of the Thai national flag have been made into products. This study is to provide understanding of how to give values and importance to the flag that is a symbol of the country.

\subsection{Concepts Used in the Study}

The researchers employed three concepts in analyzing the competitions for meanings of the colors of the Thai national flag: 1) Baudrillard (1994)'s concept of consumption of signs; 2) Woodward (1997)'s concept of identity; and 3) Habermas (1990)'s concept of the public sphere.

Baudrillard (1994), describes that in the symbolic society and the society of signs, before a product is consumed, the particular product is converted to a "sign". Converting a product, which is an object to "signs" consists of many codes such as packaging, price, brand, shelving, placing in different types of stores, and advertisement. Baudrillard claims that converting a product into signs consists of many levels of code. The reason is to make products function as cultural media to show status and prestige of the user. The codes of product hierarchy correspond with the structure of social stratification, and people know their positions in the social structure from the level of product hierarchy they consume. Therefore, individuals do not only consume the product as an "object" but also a "sign" at the same time, which corresponds with a study by Chaoprayoon (2012) on tourism development and creation of Pai tourism identity, Pai District, Mae Hongson Province. Meanings that reflect through cultural signs related to tourism, local people, and cultural signs for tourism have been created by tourists, the community, and entrepreneurs. These signs are reflected through food, clothing, souvenirs, etc. 
because signified meanings can add tourism value, encourage needs for tourism, show cultural values, the thinking system as well as value of the community. Rattanakit (2007)'s study on amuletic Buddha images: communication and the consumption of signs, found that amuletic Buddha images that were regarded more as sacred objects have become more secularized. Baudrillard found that if the supply of certain products is high, it will sell a "sign" to consumers. Amuletic Buddha images are consumed as a "sign" as well because some categories of the amulets are placed higher than others. Nevertheless, no matter how much they are consumed in a signified way, the amuletic Buddha images have to be genuine. Therefore, products are not sold only in terms of their "sign" but also in terms of product hierarchy. Rit-yu (2010) explores orthodontic fashion among teenagers who try to use their oral space for another purpose that is not a natural use, and found that teenagers utilize the signs of braces as accessories to communicate new meanings without any medical use of the dental braces they wear. For this study on the colors of the Thai national flag, the researcher uses the concept of consumption of signs in describing the meanings given to the colors of the national flag.

The concept of consumption of signs is used to describe consumption behavior of users of the flag because nowadays people do not consume only the products but they also consume the meanings of the products. Thai consumers are, thus, under the rules of signs as well. The colors of the national flag are used for different meanings, and the researcher, therefore, uses the concept of consumption of signs in describing the meanings of the colors of the flag.

Woodward (1997) describes identity as how we perceive ourselves, who we are and how we are related to others and the surroundings. Identity designates the journey of our life, and tells us who are in our group and who are different from us. In other words, identity is a definition of ourselves, of who we are, our background, our differences from others, and what we use to signify our identity. This is in accordance with Kanchanaphan (2005) who defines identity as a definition given to oneself not given by others like the one concealed in the meaning of uniqueness. Identity, thus, helps us understand the viewpoint that is different from others in society. This indicates that identity and its meaning of an individual can be designated by the individual himself or herself, and it is not necessary to be differentiated from that of others. Kaewthep (2006) notes that identity given by external sources is called "public identity", while that given by oneself is called "personal identity". This classification does not mean that personal identity is psychological identity and public identity is social identity. Rather, personal identity is how we look at ourselves and see how we are different from others, while public identity is how others look at us. Ramitanon (1997) explains that identity refers to ones that we feel "We" which is different from "They" or "Others". We do not have to have only one identity, but "We" are made up of many identities, and identities do not exist naturally, but created by society. Therefore, identity requires a process of creating likeness or similarities among "We" or "Others", or a process of identity creation at the same time.

The researcher employed the concepts of identity to analyze self or specific characteristics of groups or individuals who utilized the colors of the national flag to express themselves in many different activities because each group and each individual utilized the colors of the flag according to its or their own definitions. Hence, the researcher applied the concepts of identity in defining self/selves of users of the colors of the flag in terms of the expressions through signs.

The concept of the public sphere by Habermas (1989) which is an important issue for urban development physically referring to a common space owned and used by people in a particular society. However, in an abstract sense, it refers to a space where people can express their thoughts freely under the scope specified by society. Therefore, a public sphere is a symbol of freedom, opportunities, and indicators of the quality of life that are very important for urban society. In the same way, Wanitchayachart (2001) uses Habermas' concept of the public sphere and refers to it as a social phenomenon connected to communication that all people have equal rights in sharing their attitudes and opinions with others, which eventually can be concluded into suggestions with dynamic power to demand for public benefits. Habermas refers to this communication condition as an ideal speech situation, which has three characteristics. They are 1) every individual can communicate or speak without any rules or limitations, 2) every individual has equal rights to participate in the discourse, and 3) the communication is under a social context where individuals from every group and class can express their thoughts. Praditvitayakorn (2012) specifies that a public sphere can function as a space for the middle class to fight politically because in addition to speaking, there are opportunities for social members to participate in the public life, to check what the government is doing, and to show themselves as citizens who gather to participate in public life as well.

The concept of a public sphere describes that it is a social space where individuals meet, talk and discuss freely about many different issues. Hence, utilization of the colors of the national flag in each space with different meanings of the colors of the flag should be different in their consumption of signs, too. In analyzing the 
meanings of the colors of the flag given by people in each space who consumed them in a signified way, the researcher employed the concept of public spheres to find out the reasons why the use of the colors in each space was different.

\section{Method}

In conducting this qualitative research, the researcher gave importance to field data that were collected through in-depth interviews regarding the competitions for the meanings of the colors of the Thai national flag. The data were collected and analyzed with the following steps.

\subsection{Informants}

There were two groups of informants One group of 10 key informants consisted of people working in government organizations, and political rally participants who were part of the competition where the colors of the national flag were consumed as expressions of signs. The other group consisted of 10 secondary informants who were people in general that used the colors of the flag for expressions in terms of signs, and people who witnessed the use of the colors of the flag as expressions of signs.

\subsection{Study Area}

The main area for interviews was Hat Yai and Bangkok. The researcher used this area to collect data on the use of the colors of the flag because it was an area where the national flag or the colors of the flag were used in such a way that could be referred to as consumption of signs. In this area, data were collected from different areas used by the media such as newspaper, television, online media, sports area, government offices, and social areas. The media areas were used as data collection areas because the media space is a space where diversified information is disseminated broadly with a large number of audiences.

\subsection{Research Instruments}

For in-depth interviews, the researcher constructed the questions according to the objectives of the study. The questions were used to interview the primary and secondary key informants, and an observation form was also used for recording the data related to the use of the colors of the flag in different contexts.

\subsection{Data Collection}

Data were collected from related hard-copy and soft-copy documents online as well as research reports concerning colors of the national flag. In addition, field data were collected from rally participants who used colors of the national flag to express their political preferences, to cheer sports competitions, and to drape coffins. To conduct the interviews, the researcher went to different places such as government offices, political rally areas, and sports competitions areas. Participatory observations and non-participatory observations were conducted. For participatory observation, the researcher participated in the political rallies, sports competitions as a sports player, as a sports cheering spectator, and participated in funeral ceremonies where the national flag was used to drape coffins of officers who were killed on duty.

\subsection{Data Analysis}

In data analysis, data collected from the interviews, participatory and non-participatory observations, and related documents were classified into categories according to the study issues, decoded, interpreted, concluded with inductive reasoning, and presented descriptively.

\section{Results}

The results of the study on competitions for meanings and consumption of signs for the Thai national flag in Thai society could be classified into the following meanings in each space as follows.

\subsection{The Colors of the National Flag as a Representative of the Thai State}

Using the colors of the national flag as a representative of the Thai state is the use of the colors of the Thai national flag in international sports competitions. The colors of the flag are used on athletes' shirts of Thai national teams; the Thai national flag is waved; and cheering spectators of the Thai teams paint the colors of the flag on their faces to show that they are representatives of the Thai states.

Some of the informants reflected on the use of the colors of the national flag as the representative of the Thai state are as follows.

"The colors of the national flag are symbols representing Thai people in the whole country. The athletes wearing their sports outfits with a patch of the national flag on them represent Thai people as a whole."

(Kornwipha Chotrueang, interviewed on August 22, 2014) 
"Using the colors of the national flag in cheering the games is the use of the colors of the flag to show the country that we are from or the country of the athletes that we cheer. We show it by using the colors of the national flag while cheering."

(Mutina Sawaengha, interviewed on August 8, 2013)

"Using the colors of the Thai national flag on sports outfits or in cheering the game is for the athletes and the cheering team to show the symbol of being the Thai nation."

(Attaphon Sukniyom, interviewed on September 3, 2013)

As can be seen, the use of the colors of the national flag to indicate being the representative of the Thai state and using the colors of the flag in cheering sports is a symbol that indicates the individuals are representatives of the country. The cheering team that uses the colors of the flag has become a symbol indicating what country the team cheers. This has made the colors of the national flag a symbol that shows the existence of the nation.

\subsection{The Colors of the National Flag as Being the Same Group in a Political Space}

The colors of the national flag as a symbol to show political preferences, especially in the political rally by the People's Democratic Reform Committee (PDRC), were used as symbols for political preferences, and the utilization was more effective and more powerful than any other political rallies had ever been. This was because the PDRC chose to use the colors of the national flag "red, white, and blue". The use of the colors of the national flag and the flag itself as the symbol for this rally probably made it the only rally in the world in which colors were used to show political preferences. The colors of the national flag were painted or printed in many accessories that reflected the change from personal identity to public identity. Such accessories with the colors of the flag painted on them reflected personal taste that everyone could think of the ways they wanted to use the colors or symbol. There was development of the symbol that rally participants jointly diversified, so they did not only show protest posters as they used to do before this. The national flag and whistles that were the colors and the symbol of the rally functioned as linkages of problems of the country, and as indicators of the government's faults and frauds. The colors of the national flag in accessories reflected a change from personal identity to modification of making them correspond with people's lifestyle. Therefore, the colors of the flag are printed on eye glasses, ribbon hair bows, head bands, clothing, caps and hats, whistle chains and many other products. Chuesathapanasiri (2014) said, "Using the colors and symbol by Thais is more than using them for protest but it is a ritual activity with dynamics that can inspire people. What's more important is that the colors have become part of their way of life because we see the colors of the flag on T-shirts, jewelry, ice cream or even soap in the colors of the flag".

Some informants reflected on the use of the colors of the flag as a symbol for political preferences as follows.

"The colors of the flag show the love for the nation and love for the King"

(On-anong Phongsung, interviewed on April 4, 2013)

"The colors of the flag are the symbol of our rally because we rally to demand for righteousness, and we do it for our country".

(Prawit Phukham, interviewed on April 4, 2013)

"The colors of the national flag used in the rally show the power of the people who rally to demand for justice for Thai people in the whole country".

(Amorn Phaisan, interviewed on April 5, 2013)

"Many things with the colors of the flag on them are also symbols of the rally, and indicate our love for Thailand and to show that we are in the same group."

(Korawit Ngammanee, interviewed on April 5, 2013)

As can be seen, the colors of the national flag are used as a symbol to show political preferences, love for the nation, and to show love and respect for the King. All these reflected the use of symbols, or consumption of signs by a group of people who had the same political preferences to show other people in Thai society that people in their group had the same political views.

\subsection{The Colors of the National Flag as a Sacred Object}

Thai society is a free society in a boundary of fine traditions and cultures where the institutions of the nation, religion, and King are highly respected. The colors representing these three institutions are the colors of the national flag. Therefore, the national flag of Thailand is highly sacred and meaningful, and thus, even though 
every Thai has the right to use the national flag, there is the Thai Flag Act to follow. For example, the national flag can be used to denote the honor of deceased persons such as the president of the Privy Council, house speaker, prime minister, and president of the supreme court. In addition, it can be used for people who have received the royal Thai decorations and awards called the Ancient and Auspicious Order of the Nine Gems, persons who have died on duty or in service, or have been killed in defense of the royal family. The national flag is used to cover the body of the deceased in a royal bathing ceremony. It is also used in funerals of certain officers in the royal navy, in moving the deceased for religious reasons to denote their honor in sacrificing their lives for the country, and their bravery. Some informants reflected to show the colors of the national flag used as a sacred object are as follows.

"The deceased should be honored because they performed their duty for the country."

(Phanthanarai Chuwong, interviewed on September 27, 2014)

"While the deceased's family are sad on their loss, they are proud of the deceased at the same time."

(Mewika Khongchu, interviewed on September 30, 2014)

"The national flag of Thailand is highly respected because it is a symbol of Thailand, a nation that cannot be destroyed or disparaged."

(Nanthaphat Wongchan, interviewed on October 2, 2014)

Therefore, the colors of the Thai national flag are important and meaningful to Thai people. Individuals must treat the flag with dignity and respect. The flag is not to be despised, and the reputation of Thailand must not be spoiled through maltreatment to the flag.

\subsection{The Colors of the National Flag to Welcome HM the King's Visit}

Wherever HM the King goes, his subjects always salute him by shouting "Long live His Majesty.", and in their hands they carry a picture of their beloved King and the King's flags which has the Royal cypher "Pho. Po. Ro" and the crown on it. People are waving the national flag and the King's flag at the same time while shouting to salute the King. According to the article "The Signs of Trirong" written by King Rama IV in 1917, red refers to the blood that Thai people can sacrifice to save the country's independence; white refers to the purity of the Buddha's teachings, and Dhamma in the heart of Thais; and blue refers to the monarch. Blue was also King Rama IV's favorite color and it was the color of his birthday.

Some views on the meanings of the national flag used in welcoming and saluting HM the King were reflected by some informants as follows.

"HM the King highly deserves respect because he is such a dedicated king who always works hard for our country."

(Chintana Chuton, interviewed on September 30, 2014)

"The waving flags indicate the love of the people to the King."

(Suchat Chatkla, interviewed on September 30, 2014)

"It is an expression of love, respect, and happiness to welcome our beloved King with gratitude for his kindness and graciousness."

(Thirachat Thummanee, interviewed on October 2, 2013)

Therefore, the colors of the national flag are the colors of the monarchy. That is why groups of people or Thai people in general use the colors of the flag to show the signs of welcoming HM the King. The colors of the flag also show people's love and respect to HM the King of Thailand for his kindness and graciousness.

\subsection{The Colors of the National Flag Used to Display at Government Premises}

The colors of the national flag in the Thai flag are used to display at all government premises and offices to indicate that they are governmental spaces under supervision of the Thai government. Another purpose of displaying the Thai national flag in government premises and offices is to familiarize people who see it with the "Thong Trirong" or the tricolor flag of Thailand, which is the highest symbol that represents Thailand as a national state. The Thai national flag is flown at all government buildings including buildings of state enterprises and all other government organizations. The flag should be displayed only in a manner befitting its importance as national symbol everyday and all the time. For private organizations and houses, the guidelines for displaying of the national flag are similar. 
"The national flag should be displayed at government buildings and offices because they are the places where people go for services. Displaying of the flag is like telling people that these are government places where they can report and file their complaints."

(Suthanya Prasertsuk, interviewed on September 27, 2014)

"Displaying the colors of the national flag or the flag at government places is showing the symbol of Thai government offices and unity of Thais. Now there are many people from other countries in Thailand so displaying the flag is to show that the places are Thai official places."

(Rattana Sae Wa, interviewed on October 2, 2014).

Thus, displaying the Thai Trirong flag in government office areas is necessary and the display of the flag should be performed properly and correctly according to the flag code so that it shows dignity and unity of Thai people. Furthermore, the colors of the national flag are symbols indicating that the places are organizations of the Thai state.

\section{Discussion}

The issues of utilization of the colors of the Thai national flag as the representative of the Thai state, in sports competitions in other countries, especially the use of the colors of the flag on athletes' shirts is to show that they are representatives of Thai people and that they are from Thailand. Sports cheering spectators who paint the colors of the flag on their faces and wave the Thai national flag show their identity and show the country that they cheer. Therefore, the expressions of signs by athletes and cheering spectators are shown through the colors of the flag on their shirts, faces, and the flags they wave. Thus, they use the colors of the flag for expressions of signs representing Thailand or the nation state that the cheering spectators cheer. This corresponds with the concept of identity by Fueangfusakun (2003) who specifies that identity stems from the definition of who the person is, what background the person comes from, how that person is different from others, and what sign does that person uses to show his or her identity.

Regarding the issue of using the colors of the flag to show that individuals are politically in the same group began when a group, which called itself a red-shirt group, and a group called a yellow-shirt group rallied. The outstanding symbols used by the yellow-shirt group or People's Alliance for Democracy (PAD) were the "color" and the "object" that enhanced the unity of the group. The symbolic "color" was "yellow", and the "object" was the plastic "clapping hands", and they also used the colors of the national flag as symbol of a nation-loving group, which was People's Alliance for Democracy (PAD).

Until the time came when the a rally was organized to protest a proposed "blanket" amnesty bill. At the beginning "black" was used as a mourning sign over the death of righteousness along with protest banners, which include words like "opposing" and "protesting" the bill with a symbol similar to that of a traffic sign for a "No access...". However, when the protest was raised to a higher level to oust the Phue Thai government and the Shinawatra family, the People's Democratic Reform Committee (PDRC) used the color symbols that were more effective and more powerful than any other rallies that had happened in Thailand because the PDRC chose to use the colors of the national flag "red-white-blue". Many thought that the idea was brilliant because it was like the PDRC represented the nation and the love for the country, which was utilization of signs for patriotism. This is in congruence with a study by Chuanpipatpong (2013) who claims that each political rally used colors as symbols, and the colors of the flag, "red-white-blue" were also used for a political rally. However, in this rally, the colors of the flag were printed on products such as clothing, hats and caps, whistle chains, and many other products. The colors of the flag used as symbols for love of the country by this group of people meant nationalism, and being a nation reflects that these people protest for Thailand as a country.

The issue of using the colors of the flag as a sacred object denotes the three institutions, the nation, the religion, and the monarch that they are highly respected. The flag is used in funerals of the following important people: president of the Privy Council, house speakers, prime minister, president of the Supreme Court people who have received the royal Thai decorations an awards called the Ancient and Auspicious Order of the Nine Gems, persons who have died on duty or in service. The flag is used to cover the coffins, the body or cremated bones of the deceased in bathing ceremonies or other religious ceremonies. The use of the colors of the flag that represent the nation, religion, and the King, which are the highest institutions in funerals means that the deceased persons are respectable and praised by people in Thai society. This also to denotes that the deceased persons have sacrificed or devoted themselves for Thailand.

The issue of using the colors of the flag in welcoming HM the King, head of state, on his visits to places in the country can be seen from the past to the present. HM King Bhumibol Adulyadej has been honored and presented 
with many awards from many individuals and organizations in the country as well as those from abroad for the activities he initiated for people. Wherever HM the King visits, a large number of people always come together to welcome him. Some of them carry a photo of HM the King and the King's flag which has the Royal cypher "Pho. Po. Ro", and the crown on it, while others carry the Thai national flag to wave as a welcoming sign. It can be seen that Thai people use the colors of the flag to show their respect for the nation, religion, and the King. HM King Bhumibol Adulyadej, in particular, is highly respected and is always in the heart of Thai people. Baudrillard, 1994 analyzes that under the consumer society and society of signs, before a product is consumed, it is turned into a "sign". In other words, products which are objects are turned into different "signs". Therefore, the colors of the flag on products are turned into signs in the same way as the colors of the flag that people use to welcome HM the King to represent love, respect and admiration for the King and the monarchy institution.

The issue of using the colors of the flag by displaying the flag in government buildings and offices is to show that they are responsible for providing public services, which is the main responsibility of the government. Government organizations are non-profit because the expenses are covered by budgets allocated by the government. In carrying out the activities of providing services, the state is responsible for the actions. Therefore, in order to show that government places are supervised by the government and that they are owned by Thailand, the national flag is display in these places. According to Habermas (1989), the public sphere refers to an area with a meaning in terms of its physical characteristics that it is a common space, of which people share its use, and it is jointly owned by people in that society. In the abstract sense, it is a space where people can express what they think freely within a scope limited by society. The public sphere, therefore, indicates rights, freedom, opportunities, and indicators for the quality of life, which is important for urban people. Thus, displaying the national flag in government places to show that they belong to the government of Thailand means that they are public spaces.

Therefore, it can be seen that each space that is different from each other uses the colors of the national flag, and competes for their meanings and for the consumption of signs that are different depending on the meanings given to them by the people in each space. Consequently, the meanings given to the colors of the national flag by different groups of people in Thai society are different depending on the contexts and the definitions given by people who want to express them through their consumption of signs.

\section{Recommendations}

From this study, two recommendations can be made as follows.

Firstly, it was found in this study that in competing for the meanings of the colors of the flag, each group that uses the colors in different activities gave different definitions to the colors. Therefore, it is recommended that cautions be taken when giving meanings to the colors of the Thai national flag because the three colors of the flag, red, white, and blue symbolize the three institutions of the country, which are the nation, the religion, and the monarchy that are highly respected by Thai society.

Secondly, cautions should be taken when using the colors of the flag for expressions of signs. This is because nowadays the colors of the flag are used as symbols by many groups. The ways each group uses the colors of the flag are different. The colors of the flag are used in many types of activities such as in sports competitions, funerals of certain people, political rallies, and many other activities. Therefore, the colors of the flag are the media for driving and moving groups that can bring about social change, and can strengthen and develop the country continuously.

\section{References}

Baudrillard, J. (1994). Fashion and Signification in Baudrillard. In D. Kellner (Ed.), Baudrillard: A Critical Reader. Oxford: Blackwell.

Chaoprayoon, P. (2012). Pai: Creating identity and meanings of cultural signs for tourism (Doctoral dissertation in Administrative Science). Maejo University.

Chuanpipatpong, V. (2014). When "the colors of the national flag" are symbols for ousting the government, the only one in the world... a protest with values. Retrieved March 5, 2014, from http://www.oknation.net/blog/ LittleLee/2014/01/20/entry-1

Chuesathapanasiri, T. (2014). Dynamics of Symbols. Retrieved March 5, 2014 from http://www.oknation.net/ blog/LittleLee/2014/01/20/entry-1

Fueangfusakun, A. (2003). Identity: A review, theories, and framework of thought. Bangkok: National Research Council of Thailand. 
Gazette, R. (1986). Regulations of the Office of the Prime Minister on using, hoisting, or displaying of the Thai national flag and other flags in the Kingdom of Thailand, B.E. 2529 (1986). Bangkok: Office of the Prime Minister.

Habermas, J. (1989). The Structural Transformation of the Public Sphere: An Inquiry into a Category of Bourgeois Society. Cambridge: MIT Press.

Limolansuksakul, P. (2011). Modernity and the commoditization of Muay Thai (Master's thesis). Faculty of Liberal Arts, Prince of Songkla University.

Praditvaitayakorn, S. (2012). Public Space (Master's thesis). Faculty of Architecture, Silpakorn University.

Promphayak Phuek Phasom, C. (2003). Politics in the history of the national flag of Thailand. Bangkok: Matichon.

Ramitanon, C. (1997). Cultural identity and the change of the women studies (Master's thesis). Faculty of Social Sciences, Chiang Mai University.

Rattanakit, W. (2007). Amuletic Buddha images: communication and the consumption of signs (Master's thesis). Faculty of Journalism and Mass Communication, Thammasat University.

Rit-yu, A. (2010). Orthodontic fashion: Consumption of signs among Thai teenagers (Master's thesis in Cultural Study). Mahidol University.

Thai National Flag Museum. (2014). History, background, and characteristics of the Thai national flag. Retrieved June 4, 2014 from http://www.t-h-a-i-l-a-n-d.org/thaiflag/newsite/detail.php?id=4

Wanichayachart, B. (2001). The role of "Anjaree.Com" web site as a public sphere for female homosexuals (Master's thesis). Communication Arts, Chulalongkorn University.

Woodward, K. (Ed.). (1997). Identity and Difference. London: SAGE.

\section{Interviewees}

Amorn Phaisan (pseudonym), interviewee, interviewed by Peeranat Pratoomchartpakdee, at the Lumpini Park rally site, on April 5, 2013.

Attaphon Sukniyom (pseudonym), interviewee, interviewed by Peeranat Pratoomchartpakdee, at Hat Yai City Municipality, on September 3, 2013.

Chintana Chuton (pseudonym), interviewee, interviewed by Peeranat Pratoomchartpakdee, at Prince of Songkla University, on September 30, 2014.

Korawit Ngammanee (pseudonym), interviewee, interviewed by Peeranat Pratoomchartpakdee, at the Lumpini Park rally site, on April 5, 2013.

Kornwipha Chotrueang (pseudonym), interviewee, interviewed by Peeranat Pratoomchartpakdee, at Hat Yai City Municipality, on August 22, 2014.

Mewika Khongchu (pseudonym), interviewee, interviewed by Peeranat Pratoomchartpakdee, at Prince of Songkla University, on September 30, 2014.

Mutina Sawaengha (pseudonym), interviewee, interviewed by Peeranat Pratoomchartpakdee, at Hat Yai City Municipality, on August 8, 2013.

Nanthaphat Wongchan (pseudonym), interviewee, interviewed by Peeranat Pratoomchartpakdee, at Prince of Songkla University on October 2, 2014.

On-anong Phongsung (pseudonym), interviewee, interviewed by Peeranat Pratoomchartpakdee, at the Lumpini Park rally site, on April 4, 2013.

Phanthanarai Chuwong (pseudonym), interviewee, interviewed by Peeranat Pratoomchartpakdee, at Prince of Songkla University, on September 27, 2014.

Prawit Phukham (pseudonym), interviewee, interviewed by Peeranat Pratoomchartpakdee, at the Lumpini Park rally site, on April 4, 2013.

Rattana Sae Wa (pseudonym), interviewee, interviewed by Peeranat Pratoomchartpakdee, at Prince of Songkla University, on October 2, 2014.

Suchat Chatkla (pseudonym), interviewee, interviewed by Peeranat Pratoomchartpakdee, at Prince of Songkla University, on September 30, 2014. 
Suthanya Prasertsuk (pseudonym), interviewee, interviewed by Peeranat Pratoomchartpakdee, at Prince of Songkla University, on September 27, 2014)

Thirachat Thummanee (pseudonym), interviewee, interviewed by Peeranat Pratoomchartpakdee, at Prince of Songkla University, on October 2, 2013.

\section{Copyrights}

Copyright for this article is retained by the author(s), with first publication rights granted to the journal.

This is an open-access article distributed under the terms and conditions of the Creative Commons Attribution license (http://creativecommons.org/licenses/by/3.0/). 